\title{
Selection of Corrosion Resistant Materials for Nuclear Waste Repositories
}

\author{
Raul B. Rebak \\ Lawrence Livermore National Laboratory, Livermore, CA 94550, US
}

Keywords: Nuclear Waste, Container Materials, Corrosion

MOL. 20061026.0049

\begin{abstract}
Several countries are considering geological repositories to dispose of nuclear waste. The environment of most of the currently considered repositories will be reducing in nature, except for the repository in the US, which is going to be oxidizing. For the reducing repositories, alloys such as carbon steel, stainless steels and titanium are being evaluated. For the repository in the US, some of the most corrosion resistant commercially available alloys are being investigated. This paper presents a summary of the behavior of the different materials under consideration for the repositories and the current understanding of the degradation modes of the proposed alloys in ground water environments from the point of view of general corrosion, localized corrosion and environmentally assisted cracking.
\end{abstract}

\section{Introduction}

Radioactive materials are extensively used in a variety of applications such as medical, weapons, and power generation. Once these materials lose their commercial value, they are considered radioactive waste. Broadly, the wastes can be separated into defense (weapons) and civilian (power, medical) [1]. The safe disposal of radioactive waste requires that the waste be isolated from the environment until radioactive decay has reduced its toxicity to innocuous levels for plants, animals, and humans. Many different types of radioactive waste are produced during commercial and defense nuclear fuel cycles. One type of waste, denoted high-level waste (HLW), contains the highest concentration of radiotoxic and heat-generating species. Because of this factor, the most stringent standards for disposing of radioactive wastes are being placed worldwide on HLW, and the majority of the radioactive waste management effort is being directed toward the HLW problem. One of the most common types of HLW is the spent fuel (SF) from commercial nuclear reactors for power generation.

All of the countries currently studying the options for disposing of HLW have selected deep geologic formations to be the primary barrier for accomplishing this isolation. It is postulated that by the very nature of these geological sites, they will contain the waste for long times, limiting their spread, for example, through water flow. Most of the repository designs also plan to delay the release of radionuclides to the environment by the construction of engineered barrier systems (EBS) between the waste and the geologic formation. The principal engineered component in this multibarrier approach is the waste package, which includes the waste itself, possibly a stabilizing matrix for the waste (together termed the wasteform), and a metallic container that encloses the wasteform. Beyond the metallic containers, other barriers could be added to attenuate the impact of the emplacement environment on the containers. These barriers include, for example, the drip shield proposed in the U.S. design or a bentonite backfill proposed in several European designs [2,3]. 
The waste container may be a single vessel, but most programs generally call for concentric double walled vessels of dissimilar metals. Each vessel will have a specific function. For example, the container that directly holds the wasteform may be designed to shield radiation and facilitate safe waste handling and emplacement operations. This container may be over-packed with a corrosion-resistant outer layer. This paper addresses the long-term corrosion behavior of HLW container materials; more specifically of the outer shell of the containers. The design of the different containers for nuclear waste would vary according to the nature of the geologic formation at the site of the repository. There are more than thirty nations currently considering the geological disposal of HLW [3]: Table-I shows a list of nations, the intended geologic formation, the type of environment, and the current proposed design for the containers $[2,3]$. The material selection and its behavior in each type of emplacement will be discussed separately.

\section{Time Considerations}

In the last 15 years, the predicted length of time for the safe survival of the EBS in the HLW repository sites has increased. In 1987, most of the repository designs specified from 300 to 1000 years. In 2006, the minimum length of time specified for many repositories has increased to $10,000,100,000$ and even to $1,000,000$ years $[2,4-7]$. The requirement that a waste container survive intact for thousands of years in an irradiated elevated-temperature geologic environment has created a difficult problem for materials and design engineers to solve. The unique aspect of this problem is associated with making predictions about the corrosion behavior of container materials for these extended periods of time, since many of the alloy systems being considered have been in existence for less than 100 years. The viability of extrapolating corrosion data from short term testing to long time performance has been addressed by some investigators $[4,8]$. Other researchers have proposed models to predict the lifetime performance of container alloys $[9,10]$. The problem associated with interpreting results for long-term behavior based on accelerated testing has been addressed by the American Society for Testing and Materials (now ASTM International). The ASTM Committee C-26 on the Nuclear Fuel Cycle prepared the standard C 1174 entitled "Prediction of the Long-Term Behavior of Materials, Including Waste Forms, Used in Engineered Barrier Systems (EBS) for Geological Disposal of High-Level Radioactive Waste.” ASTM C 1174 provides guidelines on the corrosion testing of materials. ASTM C 1174 also recognizes that actual data on the long-term behavior of materials in repository-like conditions will not be available to be used in the design of the waste package. Therefore, the standard establishes that short time (e.g. 10 years) data need to be used to support the development of predictive behavior models for the response of the waste package over times as long as 10,000 years. The standard provides guidelines on how to perform accelerated corrosion tests to compensate for the shorter testing time. These acceleration factors may include the use of more concentrated solutions, higher temperatures and applied potentials. The accelerating factors described in ASTM C 1174 may be used provided the degradation (alteration) mechanism(s) remains the same. The effects of accelerating conditions should be quantified and mechanistically described before they are used for lifetime predictions.

\section{Environmental and Materials Considerations}

Many of the countries that are considering the emplacement of HLW in geological repositories have recognized the importance of an underground research laboratory (URL) for the characterization of the rock, the testing of materials for environmental degradation, and other studies. The most common host rocks for nuclear waste repositories in the world are clay, basalt and granite (Table I). The containers are intended to be located in alcoves buried vertically down from the ground level, that is, below the water table. The depth of emplacement may vary from country to country but it is generally assumed to be on 
the order of 100 to 500 meters. The only non-saturated (above the water table) environment for a repository is the one projected for the US, which is planned to be emplaced in horizontal tunnels under the ground of a mountain.

According to the value of the redox potential, an environment can be categorized as mostly reducing or mostly oxidizing. In a reducing redox potential, the cathodic reaction is controlled by the hydrogen discharge reaction. An oxidizing redox potential is established by the cathodic reactions other than hydrogen reduction, for example by the reduction of dissolved oxygen. Most of the repositories in the world will be reducing based on redox potentials, since they will rely on depth (where the solubility of oxygen in water is minimal) and a projected backfill with bentonite (Table I). The intended function of the backfill is to retard the diffusion of oxygen towards the containers and the diffusion of the radionuclides away from the containers. The repository in the USA will not have restrictions regarding the availability of oxygen to contact the containers, that is, the redox potential will be oxidizing in nature, provided an aqueous solution materializes. The important environmental parameters affecting corrosion include container temperature, groundwater chemistry (including microbial activity), groundwater flow rate, hydrostatic and lithostatic pressure (which influences water phase and container stress), and radiation flux from the waste itself.

Radiation. Theoretically, radiation can affect the corrosion behavior of the container by affecting both the container environment and its metallurgical properties. The general conclusion reached by most investigators is that the types and dose rates of radiation emitted from decaying wastes are not sufficient to degrade the properties of either the container material or its passivating oxide layer. Only gamma radiation from the HLW can affect the environment, because the other forms of radiation will not penetrate the container walls. It has been suggested that radiation may produce changes in the external environment, for example by controlling microbial activity or by radiolysis of groundwater.

Water Chemistry. The groundwaters associated with the crystalline-rock formations should all be relatively benign to most materials because of their low ionic strengths, near neutral $\mathrm{pH}$, and low concentrations of halide ions [6]. The corrosivity of these waters could increase if significant groundwater vaporization occurs when high container temperatures exist during the early times following emplacement.

Temperature. The container temperature may be influenced by the design and loading of the waste package (size, thermal output, radiation output), the rate and density of waste package emplacement, and the thermal properties of the formation. Because heat is a significant by-product of HLW decay, the temperature of all waste containers will initially increase and then decrease as the activity of the waste decays. The predicted temperature history for waste packages emplaced in a consolidated volcanic ash (tuff) formation in the U.S. is not expected to be higher than $160^{\circ} \mathrm{C}-200^{\circ} \mathrm{C}$ [6]. Typical maximum container temperatures for a number of other repository locations are expected to be lower than $100^{\circ} \mathrm{C}$ [2]. The variability in maximum temperature is due primarily to design philosophy. The temperature at a given location can be lowered by longer waste aging before emplacement, lower package loading, and lower overall repository loading. The lower temperatures may enhance the performance of the entire waste package and decrease the impact of emplacing waste on the geologic formation itself. However, a penalty is incurred for lower temperatures because higher handling and emplacement costs, along with a larger usable area, are required.

Materials. An analysis of Table I show that, except for the US, most of the materials for the containers will consist of carbon steel, stainless steel, and copper. These metals are not in the high end of the scale of corrosion-resistant alloys. That is, the emphasis of the design appears to be on a controlled environment rather than on the performance of the material itself. In contrast, the materials for the engineered barrier in the US repository are some of the most corrosion resistant materials 
available today in the market of industrial alloys. The composition of candidate alloys is given in Table II.

In general, engineers carry out the selection and characterization of the materials for the EBS and project their performance as a function of the emplacement time. However, whether or not one of these repositories is actually built may depend largely on public support and perception.

\section{Reducing Environments}

This section will cover the discussion of environmental corrosion resistance of materials planned for reducing repositories (Table I). These containers will be generally surrounded by a back fill of bentonite, which will greatly limit the availability of oxygen to the metal surface. The lack of oxygen (or other oxidizing species) will create a redox potential that will be closer to the hydrogen evolution reaction. Elements such as iron $(\mathrm{Fe})$, nickel $(\mathrm{Ni})$, and copper $(\mathrm{Cu})$ are mostly in the range of corrosion immunity at these reducing potentials in the near neutral $\mathrm{pH}$ range [11]. The most common materials under study in typically reducing environments are carbon steel, stainless steel, copper, and titanium (Tables I and II). For the least corrosive underground waters, carbon steels could be viable materials; however, for the most saline conditions, titanium alloys are also being studied.

Carbon Steel and Low Alloy Steel. Carbon and low alloy steel have been extensively tested in ground water environments for the last 30 years. Corrosion rates measured for carbon steels in granitic waters ranged from 3 to $55 \mu \mathrm{m} / \mathrm{yr}(0.12$ to $2.2 \mathrm{mils} / \mathrm{yr})$, with one study showing that the rate reaches a maximum at around $80^{\circ} \mathrm{C}$ [12]. The conditions that would lead to localized corrosion of carbon steels are quite specific and unlikely to be present in typical granitic groundwaters [13]. However, hydrogen embrittlement and hydrogen blistering of low-alloys steels is possible in granitic environments with a high rate of hydrogen production [13]. Carbon steel will also have low corrosion rates in basaltic waters Even in oxygenated solutions at $150^{\circ} \mathrm{C}$, the corrosion rate of all tested carbon steels in basaltic waters was on the order of $100 \mu \mathrm{m} /$ year. In another series of tests, 1020 carbon steel, cast carbon steel, cupronickel 90-10, and Fe9Cr1Mo steel were tested in anoxic ( $<0.1 \mathrm{mg} / \mathrm{L}$ dissolved oxygen) basaltic ground water at $200^{\circ} \mathrm{C}$ for 5 months [14]. The corrosion rates were as follows: $0.9 \mu \mathrm{m} / \mathrm{yr}$ for cupronickel 90-10 and Fe9Cr1Mo steel, $1.1 \mu \mathrm{m} / \mathrm{yr}$ for cast carbon steel and $1.4 \mu \mathrm{m} /$ year for wrought carbon steel. Under the Swedish program, researchers have studied the anoxic corrosion behavior of carbon steel and cast iron in ground water at $50^{\circ} \mathrm{C}$ and $85^{\circ} \mathrm{C}$ and the impact of the presence of copper on the type and the mechanical properties of the films formed on the iron alloys [15]. They used a barometric cell filled with a simulated ground water and monitored the redox potential in the cell at $30^{\circ} \mathrm{C}$ on a gold electrode. They determined that when steel was introduced to the cell, the redox potential decreased rapidly due to the consumption of the residual oxygen by the corrosion of the steel [15].

As part of the Japanese program of nuclear waste disposal, the passive corrosion behavior of steels was found to be dependent on variables such as ground water $\mathrm{pH}$, temperature and available dissolved oxygen [16]. Scientists in the Japanese program have raised the concern that whenever the corrosion of steel decreases due to a decrease in the oxygen content, the alkalinity in the immediacy of the steel increases. Since higher alkalinity would reduce the free corrosion potential of the steel, the process may increase the rate of hydrogen gas production that could be detrimental for the stability of the repository. In another study, it has been shown that the corrosion rate of carbon steel is dependent on the amount of bicarbonate $\left(\mathrm{HCO}_{3}{ }^{-}\right)$present in the water [17]. At bicarbonate levels of $0.1 \mathrm{M}$, similar to a potential geological disposal site in Japan, the corrosion of carbon steel is inhibited.

Carbon steel has also been identified as a candidate material for rock salt repositories in the German program. Studies were conducted to determine the corrosion response of welded and nonwelded $\mathrm{Fel} .5 \mathrm{Mn} 0.5 \mathrm{Si}$ steel in a $\mathrm{MgCl}_{2}$ rich brine (Q-brine) at $150^{\circ} \mathrm{C}$ under an irradiation field [18]. 
Welding was carried out by gas tungsten arc (GTAW) and electron beam (EB). The overall corrosion rate of both welded and non-welded materials was approximately $70 \mu \mathrm{m} / \mathrm{yr}$; however, the welded materials experienced some localized attack in the weld seam area. When the material was heat treated for $2 \mathrm{~h}$ at $600^{\circ} \mathrm{C}$, the corrosion rate of the welded material increased by approximately $40 \%$ [18].

Carbon steel and low alloy steel have also been identified as candidate materials to contain nuclear waste for an intermediate storage of 100 years in the French program [19]. The dry oxidation testing of carbon steel in dry air (less than 15 ppm water), in air plus $2 \%$ water and in air plus $12 \%$ water at $300^{\circ} \mathrm{C}$ for up to $700 \mathrm{~h}$ showed little damage to the tested coupons. When the depth of the oxide layer was extrapolated to 100 years, it resulted in less than $150 \mu \mathrm{m}$ of damage. The authors also noted little or nil water vapor effect on the oxidation rate at $300^{\circ} \mathrm{C}[19]$.

Copper. The container for the disposition of nuclear waste in Sweden will consist of a $50 \mathrm{~mm}$ thick layer of copper over cast nodular iron, which will provide the mechanical strength. Groundwater in granitic rock (as in the Swedish repository) is oxygen free and reducing below a depth of 200 meters. The redox potential is between -200 to $-300 \mathrm{mV}$ in the hydrogen scale and the pH ranges from 7 to 9 [20]. The chloride concentration in the groundwater can vary from $0.15 \mathrm{mM}$ to $1.5 \mathrm{M}$ with an equivalent amount of sodium and less calcium. The corrosion of a copper container in this reducing environment is expected to be less than $5 \mathrm{~mm}$ in 100,000 years of emplacement [20]. The corrosion of copper is mainly controlled by the availability of oxygen, sulfate, and sulfide in the groundwater. The failure time of the copper layer in the Swedish container has been modeled and it is predicted that the failure, both by general and pitting corrosion, would be higher than $10^{6}$ years under realistic emplacement conditions [21]. The anodic behavior of copper was also studied as part of the Japanese nuclear waste disposal program using potentiodynamic polarization tests in simulated ground water at $30^{\circ} \mathrm{C}$ [22]. The amount of dissolved oxygen as well as different additions of chloride, sulfate, and bicarbonate was controlled. They concluded that both sulfate and chloride promote the active dissolution of copper while carbonate is a passivating agent [22].

In the Canadian design, the thickness of the external copper layer is $25 \mathrm{~mm}$. Scientists have modeled the failure mechanism of copper as a function of the oxygen availability, the temperature, the salinity of the solution, and the redox potential. It is predicted that copper will undergo general corrosion and pitting during the initial warm and oxidizing period but only general corrosion during the subsequent longer anoxic cooler period. It has been predicted by this model that the Canadian copper container could last more than $10^{6}$ years [23]. The long-term corrosion rates of many copper-base alloys are also sufficiently low, $<20 \mu \mathrm{m} / \mathrm{yr}(0.78 \mathrm{mil} / \mathrm{yr})$ at $200^{\circ} \mathrm{C}$, that their use now appears feasible. When a copper container is buried in a mostly reducing environment, the metal will initially be in contact with oxygen, until the oxygen is fully consumed, for example by corrosion $[24,25,26]$.

It is known that copper may suffer environmentally assisted cracking (EAC) such as stress corrosion cracking (SCC) in waters containing for example ammonia and nitrite $\left(\mathrm{NO}_{2}^{-}\right)^{-}$. It has been shown that copper alloys, candidate materials for the Canadian waste containers, were susceptible to SCC using the slow strain rate technique [27]. It has been reported that the crack growth rate could be as high as $8 \mathrm{~nm} / \mathrm{s}$ [28]. However, the conditions under which the damage occurred were extreme and unrepresentative of container emplacement conditions. In the actual container, the general absence of aggressive SCC species, the limited applied strain, and the limited supply of oxygen will limit the susceptibility to environmental cracking. In another study, it has been shown that the minimum stress intensity for crack propagation in copper for the Swedish container was $30 \mathrm{MPa} V \mathrm{~m}$ when tested in a 0.3 $\mathrm{M} \mathrm{NaNO}_{2}$ solution [29]. A stress intensity of $30 \mathrm{MPa} \sqrt{\mathrm{m}}$ can be considered high for a statically loaded container having shallow defects on the surface.

Stainless Steel and Nickel Alloys. The cyclic potentiodynamic polarization method (ASTM G 61) was used to evaluate the anodic behavior of corrosion resistant alloys in oxidized Boom clay water 
(in Belgium) with varying degrees of added chloride at $90^{\circ} \mathrm{C}[30]$. The original Boom clay water is dominated by chloride and sulfate. The alloys studied included 316L SS (also with high Mo and with Ti) (S31603), Alloy 926 (N08926), Alloy 904L (N08904), Alloy C-4 (N06455) and Ti Gr 7 (R52400) (Table II). It was found that both R52400 and N06455 resisted pitting corrosion even at added chloride concentrations of $10,000 \mathrm{ppm}$ and N08926 resisted pitting up to $1000 \mathrm{ppm}$ chloride. The other alloys showed minor pitting at $100 \mathrm{ppm}$ chloride and definite pitting corrosion at the higher tested chloride concentrations [30].

Titanium. Titanium (Ti) alloys are under study as candidate materials for the containers in Canada, Japan, and Germany. The titanium alloys were selected as a potential alternative because of their excellent performance in more aggressive brine solutions compared for example to stainless steels. Corrosion rates for Ti Gr 2 and Ti Gr 12 in both oxygenated and irradiated basalt environments are very low-less than $2 \mu \mathrm{m} / \mathrm{yr}(0.08 \mathrm{mil} / \mathrm{yr})$. Failure models for the degradation of $\mathrm{Ti} \mathrm{Gr} 2$ have been published [31]. The model takes into account the crevice propagation rate as a function of temperature and oxygen availability as well as other factors such as the amount of hydrogen absorbed by the alloy during corrosion before a critical concentration for failure is reached [31]. The localized corrosion resistance of titanium alloys was widely investigated using the Tsujikawa-Hisamatsu Electrochemical (THE) method $[32,33]$. Testing showed that as the temperature and the chloride concentration increased, the repassivation potential $\left(\mathrm{E}_{\mathrm{R}, \mathrm{CREV}}\right)$ for $\mathrm{Ti} \mathrm{Gr} 1$ and $\mathrm{Ti} \mathrm{Gr} 12$ decreased to values well below the corrosion potential $\left(\mathrm{E}_{\text {corT }}\right)$ [32]. Ti $\mathrm{Gr} 12$ was more resistant to crevice corrosion than $\mathrm{Ti} \mathrm{Gr} 1$. At constant temperature and chloride concentration, $E_{\mathrm{R}, \mathrm{CREV}}$ increased as the palladium (Pd) content in the alloy increased, rapidly up to $0.008 \% \mathrm{Pd}$ and then slower between $0.008 \%$ to $0.062 \% \mathrm{Pd}$ [33]. In most of the tested electrolytes, the $\mathrm{E}_{\mathrm{R}, \mathrm{CREV}}$ was higher than $\mathrm{E}_{\mathrm{corr}}$ for the Pd containing alloys.

Titanium alloys were also investigated for their resistance to environmentally assisted cracking (EAC). One way by which titanium alloys may suffer EAC under reducing conditions is by the formation of hydrides. Slow strain rate testing was conducted using $\mathrm{Ti} \mathrm{Gr} 1$ in deaerated $20 \% \mathrm{NaCl}$ at $90^{\circ} \mathrm{C}$ at an applied potential of $-1.2 \mathrm{~V}$ (SHE) [34]. It was confirmed that cracks initiated as deep as the presence of hydrides, that is, the presence of hydride was necessary for cracks to initiate. Based on the critical cracking thickness and on the predicted amount of hydrogen generated, the authors dismissed the hypothesis that the containers may fail by cathodic EAC [34].

\section{Oxidizing Environments}

The US is currently the only country that has designed and is characterizing a nuclear waste repository with an oxidizing environment surrounding the waste package. This repository is planned to be located in Yucca Mountain, Nevada [6]. The design of the waste package has evolved in the last ten years [6,35]. Since 1998, the design specifies a double walled cylindrical container covered by a titanium alloy drip shield. The outer shell of the container will be a Ni-Cr-Mo alloy (N06022) (Table II), with an inner shell of austenitic Type 316 stainless steel (S31600). The function of the outer barrier is to resist corrosion and the function of the inner barrier is to provide mechanical strength and shield radiation. The drip shield will be made of $\mathrm{Ti} \mathrm{Gr} 7$ and a higher strength $\mathrm{Ti}$ alloy. The function of the drip shield is to deflect rock fall and early water seepage on the container [6].

\section{Corrosion Behavior of Alloy 22 (N06022)}

The container may suffer corrosion if water is present in sufficient amount at the repository site. Dry corrosion of Alloy 22 is negligible for the emplacement conditions. There are three main modes of corrosion that the container may suffer during its emplacement time. These are: (1) Uniform, general or 
passive corrosion, (2) Localized corrosion (e.g. crevice corrosion) and (3) Environmentally Assisted Cracking (e.g. stress corrosion cracking) [36]. All three types of corrosion may be influenced by the metallurgical condition of the alloy and the type of environment that is present. Metallurgical condition includes for example welded vs. wrought and annealed vs. thermally aged microstructures. The environmental aspect includes temperature, solution composition and $\mathrm{pH}$, redox potential, and effect of radiation or microbial activity. Furthermore, both the metallurgical and environmental conditions will determine the free corrosion potential $\left(\mathrm{E}_{\mathrm{corr}}\right)$ of the container. Since 1998, Alloy 22 is being intensively characterized regarding its corrosion resistance in a variety of environmental conditions.

Uniform and Passive Corrosion of Alloy 22. General corrosion (or passive corrosion) is the uniform thinning of a metal (container) at its open circuit potential or corrosion potential ( $E_{\text {corr }}$ ). In the presence of aerated multi-ionic brines, Alloy 22 is expected to remain passive at its $E_{\text {corr }}$ The degradation model for the designed container assumes that general corrosion at $\mathrm{E}_{\text {corr }}$ will progress uniformly over a large surface at a (time-independent) constant rate. This model assumes that the depth of penetration or thinning ( $\mathrm{x}$ in $\mu \mathrm{m}$ ) of the container is equal to the corrosion rate (e.g. in $\mu \mathrm{m} / \mathrm{yr}$ ) multiplied by the time ( $\mathrm{t}$ in years) that the container is exposed to an environment under which general corrosion occurs [37]. General corrosion rates are currently being measured using long-term weight-loss immersion tests and shorter-term electrochemical methods in a variety of environmental conditions.

Electrochemical impedance studies of mill annealed (MA) and aged Alloy 22 at $\mathrm{E}_{\text {corr }}$ in J-13 (repository-like) water at $95^{\circ} \mathrm{C}$ showed that after immersion times of less than three hours in normally aerated solutions, the corrosion rate was approximately $200 \mathrm{~nm} /$ year [38]. The corrosion rate did not depend on the thermal aging conditions of the tested specimens. Constant potential tests on Alloy 22 immersed in deaerated $0.028 \mathrm{M}$ and $0.5 \mathrm{M} \mathrm{NaCl}$ solutions of $\mathrm{pH} 2.7$ and 8 were performed at $20^{\circ} \mathrm{C}$ and $95^{\circ} \mathrm{C}$ [39]. After holding the potential constant for $48 \mathrm{~h}$ in the range between 0 and $+0.4 \mathrm{~V}$ [Saturated Calomel Electrode, $\mathrm{SCE}]$, they reported passive currents that translated into corrosion rates of less than $500 \mathrm{~nm} /$ year [39]. Constant potential tests were also performed on Alloy 22 in deaerated $1 \mathrm{M} \mathrm{NaCl}+0.1$ $\mathrm{M} \mathrm{H}_{2} \mathrm{SO}_{4}$ solution at temperatures between $25^{\circ} \mathrm{C}$ and $85^{\circ} \mathrm{C}$ [40]. At $75^{\circ} \mathrm{C}$ and at an applied potential of $+200 \mathrm{mV}$ [Ag/0.1MAgCl], they reported a current density of $1.58 \times 10^{-8} \mathrm{~A} / \mathrm{cm}^{2}$ after $10 \mathrm{~h}$ of testing. This current density translates into a corrosion rate of $138 \mathrm{~nm} /$ year [40]. Polarization resistance tests were carried out in the vicinity of the $\mathrm{E}_{\text {corr }}$ of Alloy 22 in simulated acidified water (SAW) [41]. SAW is a multi-component aqueous solution approximately 1000 times more concentrated than ground water and acidified to $\mathrm{pH}$ near 2.8. After an immersion of $1 \mathrm{~h}$ in deaerated conditions, the corrosion rates ranged from $480 \mathrm{~nm} /$ year at $30^{\circ} \mathrm{C}$ to $1440 \mathrm{~nm} /$ year at $90^{\circ} \mathrm{C}$. However, after one-week immersion in aerated SAW, the corrosion rate decreased by more than one order of magnitude to $23 \mathrm{~nm} / \mathrm{year}$ at $30^{\circ} \mathrm{C}$ and to $103 \mathrm{~nm} /$ year at $90^{\circ} \mathrm{C}[41]$.

It is difficult to obtain corrosion rates by weight loss of Alloy 22 in non-aggressive solutions such as simulated concentrated ground water, since the mass losses are practically negligible. The corrosion rate for Alloy 22 was in general less than $10 \mathrm{~nm} /$ year after more than 5 years immersion tests in multi-ionic solutions [42]. These corrosion rates were obtained after analyzing 122 specimens exposed at two temperatures $\left(60\right.$ and $\left.90^{\circ} \mathrm{C}\right)$, using two metallurgical conditions (wrought and welded), three electrolyte solutions ( $\mathrm{pH} 2.8$ to 10 ) and vapor plus liquid phases [42].

The low corrosion rates or passive behavior of Alloy 22 is believed to be because of the formation of a protective, chromium rich oxide film between the alloy (metal) and the surrounding electrolyte. This passive film is even stable in the presence of strong mineral acids at temperatures below $60^{\circ} \mathrm{C}$ [43]. It has been shown that the thickness of this passive film could be in the range of 5 to 6 $\mathrm{nm}$ [44]. The long-term extrapolation of the corrosion rate of Alloy 22 has been modeled considering that the dissolution rate is controlled by the injection of oxygen vacancies at the oxide film/solution 
interface [45]. It has been concluded that it is unlikely that catastrophic failure of the container may occur due to long-term passive film dissolution [45].

Localized Corrosion of Alloy 22. Localized corrosion (e.g. crevice corrosion) is a type of corrosion in which the attack progresses at discrete sites or in a non-uniform manner. The degradation model assumes that localized corrosion will only occur when $E_{\text {corr }}$ is equal or greater than a critical potential $\left(E_{c r i t}\right)$ for localized corrosion [46]. That is, if $E_{\text {corr }}<E_{\text {crit }}$, only general or passive corrosion will occur. $E_{\text {crit }}$ can be defined as a certain potential above which the current density or corrosion rate of Alloy 22 increases significantly and irreversibly above the general corrosion rate of the passive metal. In environments that promote localized corrosion, $\mathrm{E}_{\text {crit }}$ is the lowest potential that would trigger localized (e.g. crevice) corrosion. In environments that are benign towards localized corrosion, such as the simulated concentrated ground waters, $\mathrm{E}_{\text {crit }}$ is of no significance. In these environments, under sufficient polarization, the current density on a metal may increase due to transpassive behavior of the elements in the alloy or to oxygen evolution by the decomposition of water. The margin of safety against localized corrosion will be given by the value of $\Delta \mathrm{E}=\mathrm{E}_{\text {crit }}-\mathrm{E}_{\text {corr. }}$ The higher the value of $\Delta \mathrm{E}$, the larger the margin of safety for localized corrosion. It is important to note here that the values of both $\mathrm{E}_{\text {corr }}$ and $\mathrm{E}_{\text {crit }}$ depend on the surface condition of Alloy 22, the composition of the environment (e.g. chloride concentration), and the temperature. Researchers commonly use cyclic potentiodynamic polarization (CPP) (ASTM G 61) or the Tsujikawa-Hisamatsu Electrochemical (THE) method to determine localized corrosion (mostly crevice) repassivation potentials. This crevice repassivation potential is generally equated to $E_{\text {crit. }}$ In many instances, since the true value of $E_{\text {crit }}$ is not known, researchers use values of potential in cyclic polarization curves at which the current density on a test specimen reaches a given value of current density (e.g. E20 at $20 \mu \mathrm{A} / \mathrm{cm}^{2}$ in the forward scan or ER1 at $1 \mu \mathrm{A} / \mathrm{cm}^{2}$ in the reverse scan) $[39,41,47,48]$. These latter values of potential (E20, ER1, etc.) are for comparative purposes only and may not imply the occurrence of localized corrosion.

Alloy 22 is extremely resistant to localized corrosion such as pitting corrosion and crevice corrosion. Critical temperatures for pitting and crevice corrosion determined through ASTM immersion tests in aggressive solutions are always among the highest for nickel alloys. Electrochemical tests also confirmed the resistance of Alloy 22 to crevice corrosion [48,49]. CPP tests in $5 \mathrm{M} \mathrm{CaCl}_{2} \mathrm{pH} 6.4$ solutions showed that the passivity breakdown potential (E20) was higher than $800 \mathrm{mV}$ [Saturated Silver Chloride, SSC] at $75^{\circ} \mathrm{C}$ and decreased to $195 \mathrm{mV}$ [SSC] at $90^{\circ} \mathrm{C}$ [41]. Electrochemical tests show that Alloy 22 was susceptible to localized (crevice) corrosion at applied anodic potentials in pure concentrated chloride solutions such as sodium chloride and calcium chloride. However, when nitrate was added to the chloride-containing solution, the susceptibility of Alloy 22 to crevice corrosion decreased or disappeared $[39,46,47,49,50,51]$. Other oxyanions such as bicarbonate and sulfate may also inhibit crevice corrosion in some extent $[50,52]$.

Environmentally Assisted Cracking of Alloy 22. Wrought mill annealed (MA) Alloy 22 is highly resistant to EAC in most environments, including acidic concentrated and hot chloride solutions. Welded and non-welded U-bend specimens of Alloy 22 and other five nickel base alloys exposed for more than 5 years to multi-ionic solutions that represent concentrated ground water of $\mathrm{pH} 2.8$ to 10 at $60^{\circ} \mathrm{C}$ and $90^{\circ} \mathrm{C}$ were free from EAC [53]. Even though Alloy 22 is resistant to EAC in concentrated hot chloride solutions, it may be susceptible under other severe environmental conditions. Slow strain rate tests were performed using MA Alloy 22 specimens in Simulated Concentrated Water (SCW) and other solutions as a function of the temperature and applied potential [54,55]. SCW has a pH 8-10 and it is approximately 1000 times more concentrated than ground water. Alloy 22 was found susceptible to EAC in hot SCW solutions and bicarbonate plus chloride solutions at anodic applied potentials approximately $300-400 \mathrm{mV}$ more positive than $\mathrm{E}_{\text {corr }}$. It was demonstrated that the most aggressive species for $\mathrm{EAC}$ in SCW was bicarbonate [55]. In the anodic region of potentials, the susceptibility to 
EAC decreased as the temperature decreased [54]. Alloy 22 was also slightly susceptible to EAC in SCW at $-1000 \mathrm{mV} \mathrm{SSC}$, especially at ambient temperature [54].

\section{Corrosion Behavior of Titanium Alloys}

Titanium grade 7 ( $\mathrm{Ti}$ Gr 7 or R52400) was selected to fabricate the detached drip shield for the repository in Yucca Mountain [6]. Other Ti alloys of higher strength may also be used for the structural parts of the drip shield. The presence of the drip shield would deflect early water seepage from the containers. This drip shield would also deflect rock fall from the containers. Ti Gr 7 belongs to a family of Ti alloys especially designed to withstand aggressive chemical environments. The superior corrosion resistance of $\mathrm{Ti}$ and $\mathrm{Ti}$ alloys is due to a thin, stable and tenacious oxide film that forms rapidly in air and water, especially under oxidizing conditions. Ti alloys have a broad range of application as corrosion resistant materials. This includes seawater, wet chlorine, chlorinated organic compounds, and oxidizing acids (e.g. nitric and chromic acids). Some of the media in which Ti should not be used include hydrofluoric acid, dry chlorine, and hot pure sulfuric acid solutions. The family of Ti corrosion resistant alloys includes grades from 1 to 34 (ASTM B 265). Ti Gr 2 (R50400) is commercially one of the most popular grades. Other, more corrosion resistant grades, which are the focus of the current studies, include Ti Gr 7 (R52400), Ti Gr 16 (R52402) and Ti Gr 12 (R53400) (Table II). These three grades contain small amounts of alloying elements that improve the corrosion resistance of these alloys. For example, Ti Gr 7 contains 0.12-0.25\% palladium (Pd), Ti Gr 16 contains $0.04-0.08 \%$ Pd and Ti Gr 12 contains 0.2-0.4 molybdenum (Mo) and 0.6-0.9\% nickel (Ni) (ASTM 2002). A detailed review of the general, localized and environmentally assisted cracking behavior of $\mathrm{Ti} \mathrm{Gr} 7$ and other titanium alloys relevant to the application in Yucca Mountain has addressed, among other topics, the effect of alloyed palladium, the properties of the passive films, and the effect of radiation [56].

General and Localized Corrosion of Titanium Alloys. The general corrosion resistance of $\mathrm{Ti}$ Gr 7 is superior to that of $\mathrm{Ti} \mathrm{Gr} \mathrm{12;} \mathrm{however,} \mathrm{this} \mathrm{effect} \mathrm{is} \mathrm{more} \mathrm{noticeable} \mathrm{under} \mathrm{reducing} \mathrm{conditions}$ due to the beneficial effect of $\mathrm{Pd}$ [57]. Corrosion rate data for $\mathrm{Ti} \mathrm{Gr} 16$ are scarce. Some Ti alloys may be susceptible to crevice corrosion under certain conditions; however, these alloys are practically immune to pitting corrosion in halide-containing environments under most practical applications. It has been suggested that the susceptibility to crevice corrosion is due to the formation of a low $\mathrm{pH}$ reducing solution under the occluded conditions, where the corrosion rate of $\mathrm{Ti}$ is higher than in oxidizing conditions [57]. Halide and sulfate-containing solutions may induce crevice corrosion in $\mathrm{Ti}$ at temperatures higher than $70^{\circ} \mathrm{C}$. Anodic polarization of $\mathrm{Ti} \mathrm{Gr} 7$ in chloride- and fluoride-containing solutions at $95^{\circ} \mathrm{C}$ have shown that the presence of fluoride produces significantly higher current densities at potentials above the corrosion potential [58]. The presence of fluoride may have also rendered $\mathrm{Ti} \mathrm{Gr} 7$ more susceptible to crevice corrosion under anodic polarization [58].

Weight-loss, creviced, and U-bend specimens of $\mathrm{Ti} \mathrm{Gr} 7,12$ and 16 were exposed to three different electrolyte solutions simulating concentrated ground water for over five years both at $60^{\circ} \mathrm{C}$ and at $90^{\circ} \mathrm{C}$ in the vapor and liquid phases of these solutions [59]. Each titanium alloy exhibited some discoloration (due to the possible formation of an oxide film). Ti Gr 7 generally exhibited the lowest corrosion rates irrespective of temperature or solution type while $\mathrm{Ti}$ Gr 12 generally exhibited the highest corrosion rates [59]. The specimens immersed in the concentrated alkaline solution (SCW) exhibited the highest corrosion rates regardless of alloy composition. Specimens immersed in the acidified solution and the dilute alkaline solution exhibited significantly lower, and similar, corrosion rates. Ti Gr 12 generally exhibited higher corrosion rates at $90^{\circ} \mathrm{C}$ than $60^{\circ} \mathrm{C}$ [59]. There did not appear to be a temperature dependence on corrosion rate for $\mathrm{Ti} \mathrm{Gr} 7$ or $\mathrm{Ti} \mathrm{Gr} 16$. For all alloys, there did not appear to be any weld effect on the corrosion rates [59]. 
Environmentally Assisted Cracking of Titanium Alloys. Titanium and Ti alloys may suffer environmentally assisted cracking (EAC) such as hydrogen embrittlement (HE) and stress corrosion cracking (SCC). Embrittlement by hydrogen is a consequence of absorption of atomic hydrogen by the metal to form hydrides $[56,60]$. This may happen in service when the Ti alloy is coupled to a more active metal in an acidic solution. A critical concentration of hydrogen in the metal may be needed for $\mathrm{HE}$ to occur [56] The few environments that can induce SCC in Ti are absolute (anhydrous) methanol, red-fuming nitric acid and nitrogen tetraoxide. A few percent of water in these environments inhibits the $\mathrm{SCC}$ in $\mathrm{Ti}$.

Slow strain rate tests $\left(3.3 \times 10^{-6} \mathrm{~s}^{-1}\right)$ were performed using smooth specimens of Ti $\mathrm{Gr} 7$ and Ti

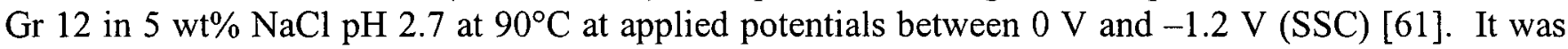
reported that for $\mathrm{Ti}$ Gr 12 (R53400), as the potential decreased, the reduction of area at rupture decreased from $40 \%$ at $0 \mathrm{~V}$ to approximately $15 \%$ at $-1.2 \mathrm{~V}$ (SSC) [61]. This behavior was attributed to a hydrogen embrittlement mechanism due to the formation of hydrides. Under the same tested conditions, the reduction of area of Ti Gr 7 (R52400) remained approximately constant at near 50\%, that is, Ti Gr 7 was more resistant to EAC than Ti Gr 12 [61]. After straining, both Ti Gr 7 and Gr 12 exhibited shallow secondary cracks at all of the tested potentials [61]. Stress corrosion cracking was reported in Ti Gr 7 specimens subjected to constant load tests in a concentrated ground water solution $\mathrm{pH} \sim 10$ at $105^{\circ} \mathrm{C}$ [62]. Results from up to 5-year immersion testing at $60^{\circ} \mathrm{C}$ and $90^{\circ} \mathrm{C}$ of U-bend specimens made of wrought and welded $\mathrm{Ti}$ Gr 7 and $\mathrm{Ti}$ Gr 16 alloys showed that these alloys were free from environmentally assisted cracking (EAC) in multi-ionic solutions that could be representative of concentrated ground water [63]. Welded Ti Gr 12 U-bend specimens suffered EAC in SCW liquid at $90^{\circ} \mathrm{C}$. Under the same conditions, non-welded Ti Gr 12 was free from cracking [63].

\section{Summary}

1. Several countries are developing geologic repositories for their high-level nuclear waste

2. Most of the repositories in the world are planned to be in stable rock formations (e.g. granite) below the water table (saturated). The US is studying a repository above the water table (unsaturated)

3. The repositories will consist of a stable geologic formation within which engineered barriers will be constructed. The main part of the engineered barrier is the container of the waste

4. The containers are in general designed as double walled metallic cylinders

5. From the corrosion point of view, most repositories will deal with reducing redox potentials with the exception of one repository, which will have a natural oxidizing environment

6. Copper, titanium, stainless steels, and even carbon steels were determined to be suitable materials for the reducing repositories.

7. Alloy 22 and $\mathrm{Ti}$ Gr 7 are being characterized for the mostly dry oxidizing environment of the US repository.

8. Materials for the engineered barriers are being evaluated for general corrosion, localized corrosion, and environmentally assisted cracking resistance

9. The metals are studied under different metallurgical conditions, such as mill annealed, welded and thermally aged

10. Environmental variables that affect corrosion behavior include the concentration and type of the aqueous electrolytes at the site (different soluble salts), temperature, redox potential, radiation and microbial activity 


\section{Acknowledgements}

This work was performed under the auspices of the U. S. Department of Energy by the University of California Lawrence Livermore National Laboratory under contract No. W-7405-Eng-48. This work was partially supported by the Yucca Mountain Project, which is part of the Office of Civilian Radioactive Waste Management (OCRWM - DOE)

\section{Disclaimer}

This document was prepared as an account of work sponsored by an agency of the United States Government. Neither the United States Government nor the University of California nor any of their employees, makes any warranty, express or implied, or assumes any legal liability or responsibility for the accuracy, completeness, or usefulness of any information, apparatus, product, or process disclosed, or represents that its use would not infringe privately owned rights. Reference herein to any specific commercial product, process, or service by trade name, trademark, manufacturer, or otherwise, does not necessarily constitute or imply its endorsement, recommendation, or favoring by the United States Government or the University of California. The views and opinions of authors expressed herein do not necessarily state or reflect those of the United States Government or the University of California, and shall not be used for advertising or product endorsement purposes.

\section{References}

1. P. A. Baisden and C. E. Atkins-Duffin, "Radioactive Waste Management," Chapter 7 in Handbook of Nuclear Chemistry, Lawrence Livermore National Laboratory, Report Number UCRL-JC-150549, 2002

2. Nuclear Energy Agency, "Engineered Barrier Systems and the Safety of Deep Geological Repositories," Organisation for Economic Co-Operation and Development (OECD Publications, 2003: Paris, France)

3. P. A. Witherspoon and G. S. Bodvarsson, "Geological Challenges in Radioactive Waste Isolation - Third Worldwide Review," Lawrence Berkeley Laboratory, Report LBNL-49767, 2001

4. D. W. Shoesmith, B. M. Ikeda, F. King and S. Sunder, "Prediction of Long Term Behavior for Radioactive Nuclear Waste Disposal," in Research Topical Symposia - Life Prediction of Structures Subject to Environmental Degradation, p. 101 (NACE International, 1996: Houston, TX)

5. L. O. Werme, "Fabrication and Testing of Copper Canister for Long Term Isolation of Spent Nuclear Fuel," Vol. 608, p. 77 (Materials Research Society, 2000: Warrendale, PA)

6. G. M. Gordon, Corrosion, 58, 811 (2002)

7. R. L. Clark, "Proposed Amendments to the Environmental Radiation Protection Standards for Yucca Mountain, Nevada" $11^{\text {th }}$ International High Level Radioactive Waste Management conference proceedings, April 30 - May 4, 2006, Las Vegas, NV, pp. 1124-1130 (American Nuclear Society, 2006: La Grange Park, IL)

8. A. A. Sagüés, "Nuclear Waste Package Corrosion Behavior in the Proposed Yucca Mountain Repository," in Scientific Basis for Nuclear Waste Management XXII, Vol. 556, p. 845 (Materials Research Society, 1999: Warrendale, PA)

9. D. D. Macdonald, M. Urquidi-Macdonald and J. Lolcma, J., "Deterministic Predictions of Corrosion Damage to High Level Nuclear Waste Canisters," ASTM Special Technical Publication, p. 143, (ASTM International, 1994: West Conshohocken, PA)

10. T. Shibata, "Statistical and Stochastic Aspects of Corrosion Life Predictions," in "A Compilation of Special Topic Reports" compiled and edited by F. M. G. Wong and J. H. Payer, p. 9-1 (Waste Package Materials Performance Peer Review, 31 May 2002)

11. M. Pourbaix, "Atlas of Electrochemical Equilibria in Aqueous Solutions" (National Association of Corrosion Engineers, 1974: Houston, TX) 
12. J. P. Simpson, R. Schenk and B. Knecht, "Corrosion Rate of Unalloyed Steels and Cast Irons in Reducing Granitic Groundwaters and Chloride Solutions," in Scientific Basis for Nuclear Waste Management IX, Vol. 50, p. 429 (Materials Research Society, 1986: Warrendale, PA)

13. G. P. Marsh, K. J. Taylor, I. D. Bland, C. Westcott, P. W. Tasker and S. M. Sharland, "Evaluation of the Localized Corrosion of Carbon Steel Overpacks for Nuclear Waste Disposal in Granite Environments," in Scientific Basis for Nuclear Waste Management IX, Vol. 50, p. 421 (Materials Research Society, 1986: Warrendale, PA)

14. R. P. Anantatmula and R. L. Fish, "Corrosion Behavior of Container Materials in Grande Ronde Basalt Groundwater," in Scientific Basis for Nuclear Waste Management X, Vol. 84, p. 295 (Materials Research Society, 1986: Warrendale, PA)

15. N. R. Smart, P. A. H. Fennell, R. Peat, K. Spahiu and L. Werme, "Electrochemical Measurements during the Anaerobic Corrosion of Steel," in Scientific Basis for Nuclear Waste Management XXIV, Vol. 663, p. 477 and p. 487 (Materials Research Society, 2001: Warrendale, PA)

16. Y. Fukaya and M. Akashi, "Passivation Behavior of Mild Steel Used for Nuclear Waste Disposal Package," in Scientific Basis for Nuclear Waste Management XXII, Vol. 556, p. 871 (Materials Research Society, 1999: Warrendale, PA)

17. J. Dong, T. Nishimura and T. Kodama, "Corrosion Behavior of Carbon Steel in Bicarbonate Solutions," in Scientific Basis for Nuclear Waste Management XXV, Vol. 713, p. 105 (Materials Research Society, 2002: Warrendale, PA)

18. E. Smailos, "Influence of Welding and Heat Treatment on Corrosion of the Candidate High-level Waste Container Material Carbon Steel in Disposal Relevant Salt Brines," Corrosion/2000, paper 00194 (NACE International, 2000: Houston, TX)

19. A. Terlain, C. Desgranges, D. Gauvain, D. Féron, A. Galtayries and P. Marcus, "Oxidation of Materials for Nuclear Waste Containers Under Long Term Disposal," Corrosion/2001, paper 01119 (NACE International, 2001: Houston, TX)

20. L. O. Werme, "Fabrication and Testing of Copper Canister for Long Term Isolation of Spent Nuclear Fuel," in Scientific Basis for Nuclear Waste Management XXIII, Vol. 608, p. 77 (Materials Research Society, 2000: Warrendale, PA)

21. K. Worgan, M. Apted and R. Sjöblom, "Performance Analysis of Copper Canister Corrosion Under Oxidizing and Reducing Conditions," in Scientific Basis for Nuclear Waste Management XVIII, Vol. 353, p. 695 (Materials Research Society, 1995: Warrendale, PA)

22. H. Imai, T. Fukuda and M. Akashi, "Effects of Anionic Species on the Polarization Behavior of Copper for Waste Package Material in Artificial Ground Water," in Scientific Basis for Nuclear Waste Management XIX, Vol. 412, p 589-596 (Materials Research Society, 1996: Warrendale, PA)

23. F. King, D. M. LeNeveau and D. J. Jobe, "Modelling the Effects of Evolving Redox Conditions on the Corrosion of Copper Containers," in Scientific Basis for Nuclear Waste Management XVII, Vol. 333, p. 901 (Materials Research Society, 1994: Warrendale, PA)

24. F. King, M. J. Quinn, C. D. Litke and D. M. LeNeveu, Corr. Sci, 37, 833 (1995)

25. F. King and M. Kolár̆, "A Numerical Model for the Corrosion of Copper Nuclear Fuel Waste Containers," in Scientific Basis for Nuclear Waste Management XIX, Vol. 412, p 555-562 (Materials Research Society, 1996: Warrendale, PA)

26. A. Honda, N. Taniguchi, H. Ishikawa and M. Kawasaki, "A Modeling Study of General Corrosion of Copper Overpack for Geological Isolation of High-Level Radioactive Waste," in Scientific Basis for Nuclear Waste Management XXII, Vol. 556, p. 911 (Materials Research Society, 1999: Warrendale, PA)

27. F. King, C. D. Litke and B. M. Ikeda, "The Stress Corrosion Cracking of Copper Nuclear Waste Containers," in Scientific Basis for Nuclear Waste Management XXII, Vol. 556, p. 887 (Materials Research Society, 1999: Warrendale, PA)

28. F. King, C. D. Litke and B. M. Ikeda, "The Stress Corrosion Cracking of Copper Containers for the Disposal of High-Level Nuclear Waste," Corrosion/99, paper 99482 (NACE International, 1999: Houston, TX) 
29. K. Petterson and M. Oskarsson, "Stress Corrosion Crack Growth in Copper for Waste Canister Applications," in Scientific Basis for Nuclear Waste Management XXIII, Vol. 608, p. 95 (Materials Research Society, 2000: Warrendale, PA)

30. F. Druyts and B. Kursten, "Influence of Chloride Ions on the Pitting Corrosion of Candidate HLW Overpack Materials in Synthetic Oxidized Boom Clay Water," Corrosion/99, paper 99472 (NACE International, 1999: Houston, TX)

31. D. W. Shoesmith and B. M. Ikeda, "Development of Modeling Criteria for Prediction Lifetimes of Titanium Nuclear Waste Containers," in Scientific Basis for Nuclear Waste Management XVII, Vol. 333, p. 893 (Materials Research Society, 1994: Warrendale, PA)

32. M. Akashi, G. Nakayama and T. Fukuda, "Initiation Criteria for Crevice Corrosion of Titanium Alloys Used for HLW Disposal Overpack," Corrosion/98, paper 98158 (NACE International, 1999: Houston, TX)

33. G. Nakayama, K. Murakami and M. Akashi, "Assessment of Crevice Corrosion and Hydrogen Induced Stress Corrosion Cracks of Ti-Pd Alloys for HLW Overpack in Deep Underground Water Environments," in Scientific Basis for Nuclear Waste Management XXVI, Vol. 757, p 771-778 (Materials Research Society, 2003: Warrendale, PA)

34. N. Nakamura, M. Akashi, Y. Fukaya, G. Nakayama and H. Ueda, "Stress-Corrosion Crack Initiation Behavior in a-Titanium Used for Nuclear Waste Disposal Overpack," Corrosion/2000, paper 00195 (NACE International, 2000: Houston, TX)

35. R. B. Rebak and R. M. McCright, "Corrosion of Containment Materials for Radioactive-Waste Isolation," Metals Handbook, Vol. 13C (ASM International, 2006, to be published)

36. R. B. Rebak and J. C. Estill, "Review of Corrosion Modes for Alloy 22 Regarding Lifetime Expectancy of Nuclear Waste Containers, in Scientific Basis for Nuclear Waste Management XXVI, Vol. 757, p 713-721 (Materials.Research Society, 2003: Warrendale, PA)

37. J. H. Lee and H. A. Elayat, "A Probabilistic Assessment Model for General Corrosion of Alloy 22 for High Level Nuclear Waste Disposal Container," Corrosion/2004, paper 04699 (NACE International, 2004: Houston, TX)

38. R. B. Rebak, T. S. E. Summers, T. Lian, R. M. Carranza, J. R. Dillman, T. Corbin and P. Crook, "Effect of Thermal Aging on the Corrosion Behavior of Wrought and Welded Alloy 22,"Corrosion/2002, Paper 02542, (NACE International, 2002: Houston, TX)

39. D. S. Dunn and C. S. Brossia, "Assessment of Passive and Localized Corrosion Processes for Alloy 22 as a High Level Nuclear Waste Container Material," Corrosion/2002, Paper 02548 (NACE International, 2002: Houston, TX)

40. A. C. Lloyd, D. W. Shoesmith, N. S. McIntyre and J. J. Noël, J. Electrochem. Soc., 150 (4), B120 (2003)

41. K. J. Evans and R. B. Rebak, "Passivity of Alloy 22 in Concentrated Electrolytes. Effect of Temperature and Solution Composition," in Corrosion Science - A Retrospective and Current Status in Honor of Robert P. Frankenthal, PV 2002-13, p. 344-354 (The Electrochemical Society, 2002: Pennington, NJ)

42. L. L. Wong, D. V. Fix, J. C. Estill, R. D. McCright and R. B. Rebak, "Characterization of the Corrosion Behavior of Alloy 22 after Five Years Immersion in Multi-Ionic Solutions," in Scientific Basis for Nuclear Waste Management XXVI, Vol. 757, p 735-741 (Materials Research Society, 2003: Warrendale, PA)

43. R. B. Rebak and J. H. Payer, "Passive Corrosion Behavior of Alloy 22," $11^{\text {th }}$ International High Level Radioactive Waste Management conference proceedings, April 30 - May 4, 2006, Las Vegas, NV, p. 493 (American Nuclear Society, 2006: La Grange Park, IL)

44. Y.-J. Kim, P. L. Andresen, P. J. Martiniano, J. Chera, M. Larsen and G. M. Gordon, "Passivity of Nuclear Waste Canister Candidate Materials in Mixed-Salt Environments," Corrosion/2002, Paper 02544, (NACE International, 2002: Houston, TX)

45. O. Pensado, D. S. Dunn and G. A. Cragnolino, "Long-Term Extrapolation of Passive Behavior of Alloy 22," in Scientific Basis for Nuclear Waste Management XXVI, Vol. 757, p 723-728 (Materials Research Society, 2003: Warrendale, PA)

46. J. H. Lee, T. Summers and R. B. Rebak, "A Performance Assessment Model for Localized Corrosion Susceptibility of Alloy 22 in Chloride Containing Brines for High Level Nuclear Waste Disposal Container," Corrosion/2004, paper 04692 (NACE International, 2004: Houston, TX)

47. B. A. Kehler, G. O. Ilevbare and J. R. Scully, Corrosion, 57, 1042 (2001) 
48. K. J. Evans, A. Yilmaz, S. Daniel Day, L. L. Wong, J. C. Estill and R. B. Rebak, "Using Electrochemical Methods to Determine Alloy 22's Crevice Corrosion Repassivation Potential," Journal of Metals, Vol 57, pp. 56-61. (2005)

49. R. B. Rebak, "Factors Affecting the Crevice Corrosion Susceptibility of Alloy 22," Corrosion/2005, paper 05610 (NACE International, 2005: Houston, TX)

50. D.S. Dunn, Y.-M. Pan, K.T. Chiang, L. Yang, G.A. Cragnolino and X. He, "The Localized Corrosion Resistance and Mechanical Properties of Alloy 22 Waste Package Outer Containers," Journal of Metals, Vol 57, pp. 49-55 (2005)

51. G. O. Ilevbare, K. J. King, S. R. Gordon, H. A. Elayat, G. E. Gdowski and T. S. E. Gdowski, "Effect of Nitrate on the Repassivation Potential of Alloy 22 in Chloride-Containing Environments," J. of the Electrochemical Society, 152, B547-B554 (2005)

52. G. O. Ilevbare, "Effect of Sulfate on the Passive and Crevice Corrosion Properties of Alloy 22 in $4 \mathrm{M}$ Sodium Chloride," Corrosion, 62, 340 (2006).

53. D. V. Fix, J. C. Estill, G. A. Hust, L. L. Wong and R. B. Rebak, "Environmentally Assisted Cracking Behavior of Nickel Alloys in Simulated Acidic and Alkaline Waters Using U-bend Specimens," Corrosion/2004, Paper 04549 (NACE International, 2004: Houston, TX)

54. . K. J. King, L. L. Wong, J. C. Estill and R. B. Rebak, "Slow Strain Rate Testing of Alloy 22 in Simulated Concentrated Ground Waters," Corrosion/2004, Paper 04548, (NACE International, 2004: Houston, TX)

55. K. T. Chiang, D. S. Dunn and G. A. Cragnolino, "The Combined Effect of Bicarbonate and Chloride Ions on the Stress Corrosion Cracking Susceptibility of Alloy 22," Corrosion/2006, Paper 06506, (NACE International, 2006: Houston, TX)

56. F. Hua, K. Mon, P. Pasupathi, G. M. Gordon and D. W. Shoesmith, "Corrosion of Ti Grade 7 and Other Ti Alloys in Nuclear Waste Repository Environments - A Review," Corrosion/2004, Paper 04698 (NACE International, 2004: Houston, TX)

57. R. W. Schutz, "Platinum Group Metal Additions to Titanium: A Highly Effective Strategy for Enhancing Corrosion Resistance," Corrosion, 59, 1043 (2003)

58. C. S. Brossia and G. A. Cragnolino, "Effects of Environmental and Metallurgical Conditions on the Passive and Localized Dissolution of Ti-0.15\%Pd," Corrosion, 57, 768 (2001)

59. L. L. Wong, J. C. Estill, D. V. Fix and R. B. Rebak, "Corrosion Characteristics of Titanium Alloys in MultiIonic Environments," PVP-Vol. 467, 63 (ASME, 2003: New York, NY)

60. C. L. Briant, Z. F. Wang and N. Chollocoop, Corrosion Science, 44, 1875 (2002)

61. A. K. Roy, M. K. Spragge, D. I. Fleming and B. Y. Lum, Micron, 32, 211 (2001)

62. L. M. Young, G. M. Catlin, G. M. Gordon and P. L. Andresen, "Constant Load SCC Initiation Response of Alloy 22 (UNS N06022), Titanium Grade 7 and Stainless Steels at $105^{\circ} \mathrm{C}$," Corrosion/2003, Paper 03685 (NACE International, 2003: Houston, TX)

63. D. V. Fix, J. C Estill, L. L. Wong and R. B. Rebak, "Susceptibility of Welded and Non-Welded Titanium Alloys to Environmentally Assisted Cracking in Simulated Concentrated Ground Waters," Corrosion/2004, Paper 04551 (NACE International, 2004: Houston, TX) 
Table I

Different Types of Repository Design Mainly for HLW and SF [2,3]

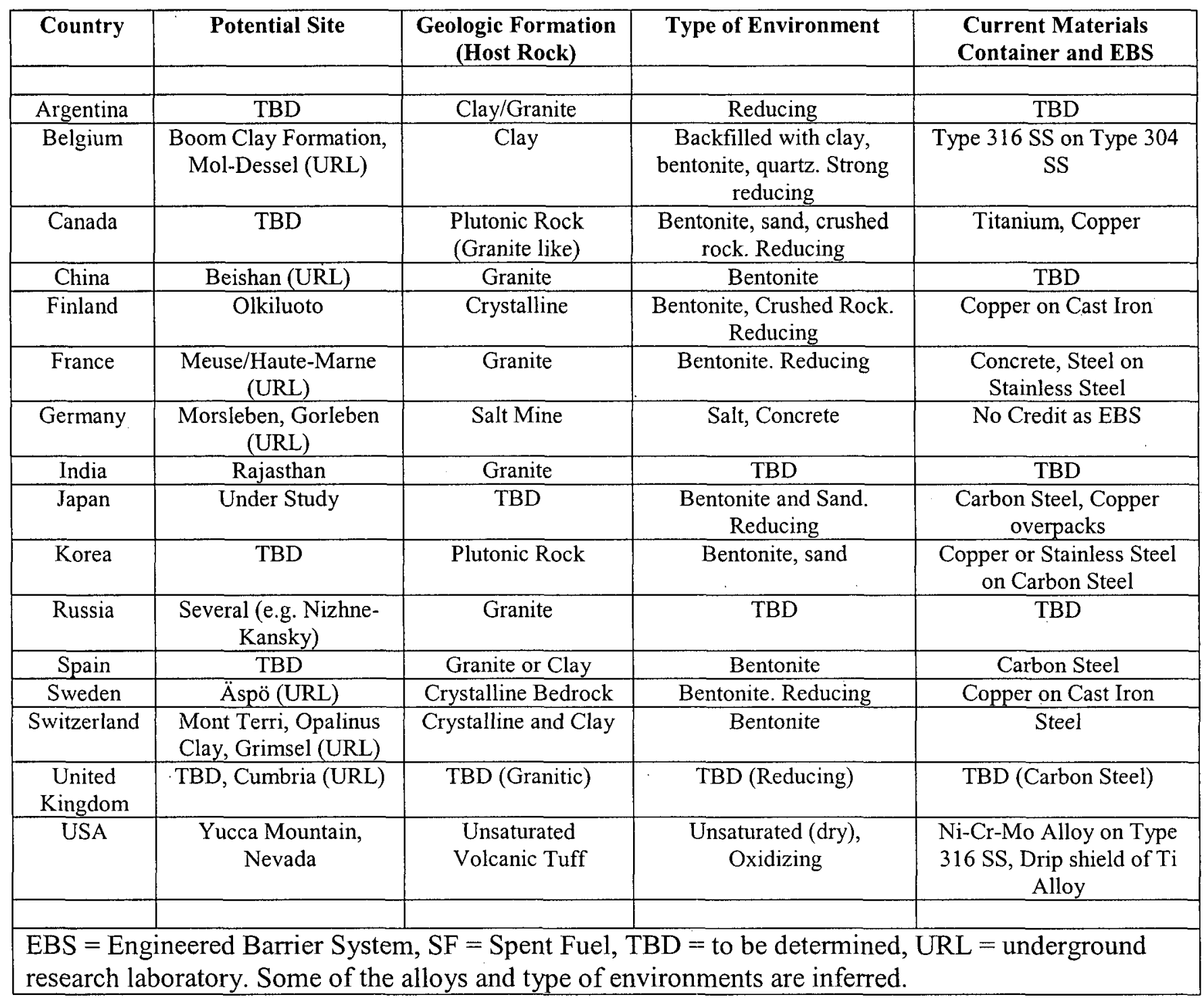


Table II

Approximate Chemical Composition (in weight percent - wt \%) for Candidate Alloys

\begin{tabular}{|c|c|c|c|c|c|c|c|c|c|}
\hline Alloy & UNS & ASTM & $\mathrm{Cr}$ & $\mathbf{C u}$ & $\mathrm{Fe}$ & Mo & $\mathrm{Ni}$ & $\mathbf{T i}$ & Other \\
\hline Gray cast iron & $\begin{array}{l}\text { F10001- } \\
\text { F10012 }\end{array}$ & $\begin{array}{c}\text { A319- } \\
\text { A159 }\end{array}$ & & & -95 (bal) & & & & 3-3.5 C, 2-2.4 Si. $0.8 \mathrm{Mn}$ \\
\hline 1018 carbon steel & G10180 & A29 & & & $\sim 98$ (bal) & & & & $0.18 \mathrm{C}, 0.5 \mathrm{Mn}$ \\
\hline 4130 alloy steel & G41300 & A29 & 1.0 & & $\sim 97$ (bal) & 0.2 & & & $0.3 \mathrm{C}, 0.5 \mathrm{Mn}$ \\
\hline $2.25 \mathrm{Cr}-1 \mathrm{Mo}$ & K30736 & A213 & 2.25 & & bal & 1 & & & $0.05 \mathrm{C}, 0.4 \mathrm{Mn}, 0.2 \mathrm{~V}$ \\
\hline $90-10$ cupronickel & C70600 & B111 & & $\sim 88$ (bal) & 1.3 & & 10 & & $1 \max \mathrm{Mn}, 1 \max \mathrm{Zn}$ \\
\hline Type 304 & S30400 & A182 & 19 & & $\sim 70$ (bal) & & 9 & & $2 \max \mathrm{Mn}, 1 \max \mathrm{Si}$ \\
\hline Type 316 & S31600 & A182 & 17 & & 67 (bal) & 2.5 & 12 & & $2 \max \mathrm{Mn}, 1 \max \mathrm{Si}$ \\
\hline Type 416 & S41600 & A194 & 13 & & $\sim 85$ (bal) & $0.6 \max$ & & & $1.25 \max \mathrm{Mn}, 1 \max \mathrm{Si}$ \\
\hline Monel 400 & N04400 & $\mathrm{B} 127$ & & $\sim 32$ (bal) & $2.5 \max$ & & 66.5 & & $2 \max \mathrm{Mn}$ \\
\hline Incoloy 825 & N08825 & $\mathrm{B} 163$ & 21.5 & 2.2 & -30 (bal) & 3.0 & 42 & 0.9 & $1 \mathrm{max} \mathrm{Mn}, 0.5 \max \mathrm{Si}$ \\
\hline Inconel 625 & N06625 & B366 & 21.5 & & $5 \max$ & 9.0 & $\sim 60$ (bal) & 0.2 & $4 \mathrm{Nb}, 0.5 \mathrm{max} \mathrm{Mn}$ \\
\hline Hastelloy C-276 & N10276 & $\mathrm{B} 575$ & 16 & & 5 & 16 & $\sim 60$ (bal) & & $4 \mathrm{~W}, 2.5 \max \mathrm{Co}$ \\
\hline Hastelloy C-4 & N06455 & B575 & 16 & & $3 \max$ & 16 & $\sim 65$ (bal) & & $2 \max \mathrm{Co}$ \\
\hline Hastelloy C-22 & N06022 & B575 & 22 & & 4 & 13 & $\sim 57$ (bal) & & $3 \mathrm{~W}, 2.5 \max \mathrm{Co}$ \\
\hline Ti Gr 2 & R50400 & $\mathrm{B} 265$ & & & $0.3 \max$ & & & $\sim 99$ (bal) & $0.25 \max \mathrm{O}$ \\
\hline Ti Gr 7 & R52400 & $\mathrm{B} 265$. & & & $0.3 \max$ & & & $\sim 98$ (bal) & $0.2 \mathrm{Pd}, 0.25 \max \mathrm{O}$ \\
\hline Ti Gr 16 & R52402 & $\mathrm{B} 265$ & & & $0.3 \max$ & & & $\sim 98$ (bal) & $0.06 \mathrm{Pd}, 0.25 \max \mathrm{O}$ \\
\hline Ti Gr 12 & R53400 & B265 & & & $0.3 \max$ & 0.3 & 0.8 & $\sim 98$ (bal) & $0.25 \max \mathrm{O}$ \\
\hline Ti Gr 29 & R56404 & $\mathrm{B} 265$ & & & $0.25 \max$ & & & $\sim 90$ (bal) & $6 \mathrm{Al}, 4 \mathrm{~V}, 0.08-0.14 \mathrm{Ru}$ \\
\hline
\end{tabular}

